\title{
New Brunswick's "J aakko Pöyry" report: perceptions of senior forestry officials about its influence on forest policy ${ }^{1}$
}

\author{
by W m. (Bill) Ashton² and Bill Anderson ${ }^{3}$
}

\begin{abstract}
Pending limited fibre supplies in New Brunswick are of concern to the forest industry, provincial government departments, and special interest groups, alike. All three of these stakeholders employ foresters, and all three are or should be involved in setting public policy regarding N ew Brunswick's forests. This paper uses a multifaceted framework to assess the role of foresters in the current policy debate regarding softwood fibre supplies that has resulted from New Brunswick's "Jaakko Pöyry" report. The conclusions from this study are that i) both forest policy and the policymaking process in New Brunswick have largely been determined by industry- and government-commissioned reports; ii) the policy-making process remains undefined; and iii) all the stakeholders see a need to improve communications.
\end{abstract}

Key words: forest policy; Jaakko Pöyry report; New Brunswick; perceptions; public policy making.

\section{RÉSUMÉ}

Les diminutions appréhendées d'approvisionnement en fibre au Nouveau-Brunswick constituent une source d'inquié tude pour l'industrie forestière, les ministères provinciaux intéressés et pour les groupes d'intérêts spéciaux et semblables. Ces trois intervenants embauchent des forestiers et tous les trois sont ou devraient participer à l'établissement de politiques publiques portant sur les forêts du Nouveau-Brunswick. Cet article utilise un cadre à plusieurs volets pour évaluer le rôle des forestiers au sein du débat politique actuel portant sur les approvisionnements en fibre de résineux découlant du rapport de la firme Jaakko Pöyry sur le N ouveau-Brunswick. Les conclusions de cette étude sont que i) tant les politiques forestières que le processus de décision en matière de politiques au N ouveau-Brunswick ont été principalement déterminés par l'industrie et les rapports commandés par le gouvernement; ii) le processus de décision demeure indéfini; et iii) tous les intervenants constatent la nécessi té d'améliorer les communications.

Mots clés : politique forestière, rapport Jaakko Pöyry; Nouveau-Brunswick; perceptions; décision publique.

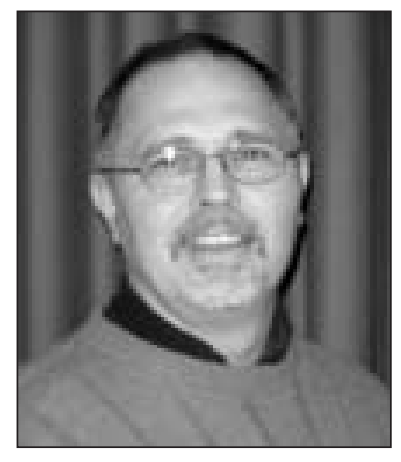

Wm. (Bill) Ashton

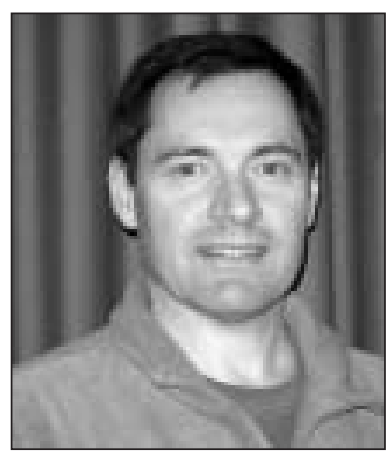

Bill Anderson

\footnotetext{
1Paper presented at the Second Eastern Canada/USA (CANUSA) Forest Science Conference, Fredericton, New Brunswick, October 15-16, 2004.

${ }^{2}$ Doctoral studies student, College of Extended Learning, University of New Brunswick, Fredericton, New Brunswick E3B 5A3. E-mail: ashton@unb.ca

${ }^{3}$ Graduate student in the University of N ew Brunswick's Faculty of Forestry and Environmental Management, employed by Natural Resources Canada, Canadian Forest Service - Atlantic Forestry Centre, P.O. Box 4000, Fredericton, New Brunswick E3B 5 P7. E-mail: banderso@nrcan.gc.ca
}

\section{Introduction}

Despite the fact that the forest sector is one of the oldest and largest sectors in both the New Brunswick and the Canadian economies, forest policy making remains a mystery to key stakeholders in the sector and the general public. There is no established process in place. This paper examines a policy-making effort issuing from a recent report on softwood fibres in New Brunswick, commonly called the "Jaakko Pöyry" report. The authors analyze the policy-making process by focusing on the perceptions of senior forestry advisors employed by the three stakeholders, namely the traditional forest policy stakeholders of government and forest industry, and an environmental non-governmental organization (ENGO). In-depth interviews were conducted with these forest policy makers, who were directly involved in many aspects of this report, and in forest policy more generally. When a messy policy-making process is combined with three often opposing views, the stage is set for both the expected and the unforeseen to transpire - and indeed they did.

\section{Managing More Than J ust Trees}

In 2002, the internationally known "Jaakko Pöyry" Management Consulting firm of New York was commissioned to prepare a report on the stewardship and management of Crown lands in N ew Brunswick. This initiative was 
funded jointly by the New Brunswick Department of Natural Resources (NBDNR) and the New Brunswick Forest Products Association, representing forest industry.

Public policies rarely come unannounced. However, more often than not, they result in something unexpected. As a case in point, the softwood fibre policy in New Brunswick was anticipated, yet it holds some surprises. Sometimes, policy is initiated to offset the consequences of a previous policy's implementation. Although it is not clear that the "Jaakko Pöyry" report was commissioned in response to a previous policy on protected areas, it seems likely. The New Brunswick government had released a Protected Areas Strategy in 2000 (N BDN R 2003a). Claiming it used the best available scientific information, the government proposed nearly a dozen areas that would be set aside under this strategy. Some forecast that this strategy would result in a fibre shortfall in the province; others argued that an oversupply of capacity existed. The provincial government held broad public consultations on protected areas. Opposition to the strategy, chiefly from forest industry, was very vocal because the withdrawal of forested lands from Crown licenses was of major concern to the industry. Industry spokespeople cited negative economic impacts, job losses, and resulting community impoverishment should the protected areas policy be adopted. However, in 2003, the government proclaimed the Protected Natural Areas Act, under which 30 areas, including ten new ones as a result of the public consultations mentioned above, were set aside. In total, more than 153000 ha are conserved under this Act, representing all seven ecoregions in the province. The ten new protected areas removed almost 150000 ha of Crown land from active forest management. Before the Act was proclaimed, another policy initiative emerged, driven large ly by the forest industry. Seeing a portion of their wood supplies removed through protection and other forest values, industry redoubled its call for a timber objective for Crown land. The "Jaakko Pöyry" report was the result of this policy initiative.

The report was released in November 2002; its official title is "New Brunswick Crown Forests: Assessment of Stewardship and Management" (Jaakko Pöyry Consulting 2002). Its recommendations addressed such issues as: increasing the annual allowable harvest on Crown lands; improving public participation; enhancing forest manage ment and supervision; addressing wildlife and biodiversity; and increasing research and development. It concluded that intensive forest management (increasing planting and precommercial thinning on Crown land from current levels of $21 \%$ and $24 \%$, respectively, to $40 \%$ and $15 \%$, respectively) could double the wood supply within 50 years (Jaakko Pöyry Consulting 2002). These recommendations were controversial, and raised significant concerns with the public, professional groups, and government foresters. In response, a provincial Legislative Select Committee on Wood Supply (LSCWS 2004) conducted a series of 13 public hearings in the fall of 2003. Forest industry continued to stress the need for a secure softwood fibre supply. A credible report was thought to be the best way to garner the necessary support. The financial institutes were said to be seeking assurances that the industry would have a secure wood supply, before financing further investments in their operations.
Forest industry has been seeking a softwood timber priority for Crown lands for many years. In 1982, industry agreed with NBDNR to a 5-year planning cycle, directed by a vision statement (NBDNR 2000). In return, industry was granted 25-year tenures on Crown lands. These tenures were "evergreen" or continuous, providing the 5-year plans were submitted to government. Erdle and Sullivan (1998) concluded that significant cooperation and gains toward sustainable development have resulted from these plans. In 2001, after three government vision documents and nearly 20 years of forest management planning, industry found itself no closer to having a timber objective on Crown land. The non-timber objectives for wildlife, water, and biodiversity, for example, all eclipsed the importance of a timber objective. Given this situation, industry concentrated its efforts on securing the necessary timber objective on Crown land by commissioning the "Jaakko Pöyry" report (Jaakko Pöyry Consulting 2002).

\section{Softwood Lumber Policy Debate}

In 2002, the forest industry contributed $\$ 1.7$ billion to the NB economy, representing about $9 \%$ of the provincial gross domestic product, and generating 17,300 direct and 6,100 indirect jobs (APEC 2003). Crown lands are divided among six large forestry companies managing ten licenses. Another 80 smaller companies have an allocation of wood from Crown land, processing about 55\% of the wood harvested from Crown lands (LSCWS 2004).

The New Brunswick Crown Lands and Forest Act (Government of New Brunswick 1980) controls the harvest in relation to the longer term. The harvest was set at a sustainable level, to ensure a constant, non-declining volume of wood would be harvested for at least 80 years into the future (LSCWS 2004). The lowest inventory of stock was projected to occur around 2030 (Erdle and Sullivan 1998). This low point sets the softwood harvest at 3.3 million cubic meters per year. Future softwood supply was forecasted to increase by $37 \%$ to 4.5 million cubic metres per year by 2047 (LSCWS 2004). As such, the limits to softwood growth are biological, with no tangible way to increase the sustainable harvest of softwood over the next 40 years.

In late 2002 and early 2003, two policy directions - protection and sustaining harvest levels - embarked on a potential collision course in N ew Brunswick. This situation extended beyond bilateral discussions between the six forest companies and the provincial government. It also involved private woodlot owners, 14 forest-dependent communities, and related interest groups, ranging from within New Brunswick to international organizations. From a policymaking viewpoint, how do we make sense of this situation?

\section{Public Policy Making}

New Brunswick's dilemma is reflected across the country and, indeed, across the continent. Although the forest economy is one of the oldest in Canada and the US, yet it remains without a policy-making process. Bilateral negotiations between the forest industry and government have been the norm over the past hundreds of years. Howlett and Rayner (2001) characterize Canada's current forest policy as public forest management for private timber harvest. Only in the last two to three decades in Canada, has public 
involvement been considered a legitimate part of forest policy making (Stefanick 2001). A definitive process for making forest policy remains illusive. There are currently as many processes as there are writers in this field. To define an approach for examining the softwood policy situation in New Brunswick, both broader public policy processes and US and Canadian forest policy examples were considered. For example, public policy can be defined generally in terms of whatever governments choose to do or not to do (Brooks and Miljan 2003). The government is the primary policy actor, in part because it makes the laws within a democratic society. Thus, Clawson (1975) defines forest policy as all public actions taken by governments that significantly affect the use and management of public and private forests. Furthering this view of forest policy, Cashore (2001) defines it as how governments and private governance systems influence the use of forest resources. Expanding the definition to include the forest industry (as a private system) more accurately reflects the New Brunswick situation. For the purposes of this discussion, forest policy will be considered as the direct and indirect actions taken by government, the forest industry, and ENGOs that significantly affect the use and management of public and privateforests. We acknowledge that not all the policy stakeholders are included in this paper, but those that we have interviewed do have considerably different perceptions on policy.

Wilson (2001) outlines the forest policy cycle as a fivestep process that includes: agenda setting, problem definition, policy development, policy implementation, and policy monitoring and evaluation. This is a rational planning process. Brooks and Miljan (2003) also used a rational process. For our research, we have drawn from these two sources to derive a policy process, and as there was no evidence of a published process, we favoured a more generic policy process.

\section{NB Policy Stakeholders}

The Crown Lands and Forest Acts (CLFA) (Government of New Brunswick 1980) permits parcelling of Crown forest lands into timber licenses, using a legal contract with the larger companies. A 5-year planning cycle enables Crownland forest management to respond to changes in social values, economic situation, resource information, and knowledge about how the forest grows. The goals and objectives pertaining to timber and non-timber values are detailed 2 years in advance of the forest management plans, in a report called the Vision document (NBDNR 2000).

A wide range of stakeholders can be involved in a forestpolicy process, including municipal and provincial governments, forest industry and its associations, woodlot owners and their organizations, environmental and conservation organizations, academia, forest contractors and consultants, equipment retailers, professional associations, First Nations, and the informed public. For the purposes of this study, only three of these stakeholders were examined. Two of these organizations traditionally have been the dominant players in the forest-policy development process in New Brunswick, namely the Department of Natural Resources and the N ew Brunswick Forest Products Association, representing the forest industry. The third stakeholder we canvassed is the Conservation Council of New Brunswick, an
Table 1. Forest policy chronology

\section{Time Line Actions/Reports}

$2001 \quad$ Protected areas strategy report

2002 Jaakko Pöyry report

$2003 \quad$ Protected Areas Act implemented

Riparian zone study (unpublished)

Radio ads

Crown lands network established

APEC report

Govt staff response to "Jaakko Pöyry" report

Select Legislative Committee hearings

2004

Select Legislative Committee report

active forest policy advisor who we refer to as the ENGO. What follows is a description of the method used to collect information, followed by our findings and conclusions.

\section{Survey Method}

Our intent was to better understand the policy advisor's role in policy making in general and specific terms, using the "Jaakko Pöyry" report as a case in point. Semi-structured interviews were conducted with one senior official from each of the three stakeholders. The interviews focused on three topics: the policy process related to the softwood lumber supply debate; what the three stakeholders saw as the role of policy advisors in the policy process; and what improvements, if any, were seen as necessary.

There are two key constraints on our findings. First, only one person from each of the three stakeholder groups was interviewed. It would be inappropriate to generalize the findings to others in the same organization or beyond this particular forest policy discussion. Second, policy making involves more than these three stakeholders. These three, however, do have viewpoints that are, at times, similar, and at other times, divergent. Together, their opinions and actions make for a dynamic policy-making situation, as noted in Table 1 and explained in the next section.

\section{Dynamics of Forest Policy Making in New Brunswick} Wilson (2001), in his outline of the forest-policy cycle, clearly sees agenda setting as a key starting point. One such moment in forest policy making in New Brunswick occurred on 14 September 2001, when a number of licensees and sub-licensees sent a letter to the government calling for, among other things, wood supply objectives that maintain the 1997-2001 softwood harvest levels at $3.3 \mathrm{~m}^{3} /$ ha/year and double the sustainable harvest by 2050, third-party audits on Crown lands, and simplified management procedures to improve cost efficiencies. Some 3 years later, the government policy official saw this as the beginning of a new policy initiative dealing with softwood fibre. By then, the protected areas strategy was drawing to a conclusion. The associated legal aspects of a protected areas act were being prepared inside government, leaving open an opportunity for the forest industry to advance a fibre policy request. Others, however, saw it differently. 
Table 2. Perceptions of policy making when focusing on the "J aakko Pöyry" report

\begin{tabular}{|c|c|c|c|}
\hline Policy Process Steps & $\begin{array}{l}\text { ENGO } \\
\text { Forestry policy advisor }\end{array}$ & $\begin{array}{l}\text { Government Forester } \\
\text { Registered professional forester }\end{array}$ & $\begin{array}{l}\text { Forest Industry Forester } \\
\text { Forestry policy advisor }\end{array}$ \\
\hline $\begin{array}{l}\text { Problem Identified } \\
\text { W hat were the } \\
\text { reasons for JPR? }\end{array}$ & $\begin{array}{l}\text { - Outdated CLFA } \\
\text {-1992 request public input } \\
\text {-2001 FI wanted secure SW } \\
\text { supply } \\
\text { - SW supplies limited } \\
\text { - Leaked letter Sept 14, } 2001\end{array}$ & $\begin{array}{l}\text { - SW supplies decreasing } \\
\text { - FI needed secure SW supply } \\
\text {-Vision report lacks timber } \\
\text { objectives } \\
\text { - SW harvest down } 5.3 \% \\
\text { since } 1982\end{array}$ & $\begin{array}{l}\text { - FM planning lacks timber } \\
\text { objectives } \\
\text { - Timber land base reduced 32\% } \\
\text { since } 1982\end{array}$ \\
\hline $\begin{array}{l}\text { Policy Formulated } \\
\text { W hat role did you play? }\end{array}$ & $\begin{array}{l}\text { - Refused to participate in } \\
\text { consultation for JPR } \\
\text { •"Call to arms," getting others } \\
\text { involved in commenting on } \\
\text { the JPR }\end{array}$ & $\begin{array}{l}\text { - Paid } 50 \% \text { of costs of JPR } \\
\text { - Kept focus on SW } \\
\text { - Steering Cmt member for JPR } \\
\text { - Avoided larger review of } \\
\text { Crown lands } \\
\text { - Insisted on answers to four } \\
\text { questions by Minster }\end{array}$ & $\begin{array}{l}\text { - Paid } 50 \% \text { of costs of JPR } \\
\text { - Steering Cmt member for JPR } \\
\text { - Kept focus on SW } \\
\text { - Avoided larger review of } \\
\text { Crown lands } \\
\text { - Requested socio-economic } \\
\text { report (APEC) }\end{array}$ \\
\hline $\begin{array}{l}\text { Laws } \boldsymbol{\&} \text { Regulations } \\
\text { Are new laws needed? }\end{array}$ & $\begin{array}{l}\text {-Very vocal during public } \\
\text { hearings, } 2003 \\
\text { - Need CLFA reviewed }\end{array}$ & $\begin{array}{l}\text { - Need to manage annual FM } \\
\text { plan cycle with 5-year Vision } \\
\text { statement cycle, with Select } \\
\text { Cmt's report } \\
\text { - SW lumber only one piece of } \\
\text { a new forest policy initiative }\end{array}$ & $\begin{array}{l}\text {-CLFA is working, best in } \\
\text { Canada } \\
\text { - Need to include timber } \\
\text { objectives in FM plans and } \\
\text { Vision document }\end{array}$ \\
\hline $\begin{array}{l}\text { Implementation } \\
\text { What happens now? }\end{array}$ & $\begin{array}{l}\text { - Too early to know, sense more } \\
\text { change is coming } \\
\text { - DNR 3-4 year work plan } \\
\text { - Govt's small majority a factor }\end{array}$ & $\begin{array}{l}\text { - Select Cmt release report in } \\
\text { Sept'04 }\end{array}$ & $\begin{array}{l}\text { - Business as usual } \\
\text {-Add timber objective }\end{array}$ \\
\hline $\begin{array}{l}\text { Evaluation } \\
\text { W hat does the current } \\
\text { situation look like? }\end{array}$ & $\begin{array}{l}\text { - No public process } \\
\text { - M ajor change needed in CLFA } \\
\text { - New forest policy needed }\end{array}$ & $\begin{array}{l}\text { - Need to prepare to review CLFA } \\
\text { - FI expecting a timber growing } \\
\text { objective in JPR } \\
\text {-DNR staff respond to JPR }\end{array}$ & $\begin{array}{l}\text { - Need to include timber } \\
\text { objective } \\
\text { - New forest policy needed } \\
\text { - Identified key changes for new } \\
\text { forest policy }\end{array}$ \\
\hline $\begin{array}{l}\text { Tools } \\
\text { W hat tools did you use } \\
\text { in this policy process? }\end{array}$ & $\begin{array}{l}\text {-Access to Govt information } \\
\text { requests } \\
\text { - Radio \& newspaper ads, emails, } \\
\text { newsletter, website } \\
\text { - Formed the Crown lands } \\
\text { network } \\
\text { - Lobbied govt for evening } \\
\text { hearings by Select Cmt }\end{array}$ & $\begin{array}{l}\text { - } 3 \text { staff seconded to Select Cmt } \\
\text { - Internal staff report } \\
\text { - Funded JPR ( } 50 \% \text { ) } \\
\text { - Select Cmt web site } \\
\text { - Select Cmt } 13 \text { public hearings } \\
\text { in } 7 \text { locations, including } \\
\text { evening sessions }\end{array}$ & $\begin{array}{l}\text { - Funded JPR ( } 50 \% \text { ) } \\
\text { - Path Forward Proposal (2003) } \\
\text { - Riparian buffers on Crown } \\
\text { lands report } \\
\text {-APEC report (2003) }\end{array}$ \\
\hline $\begin{array}{l}\text { Improvements } \\
\text { Institutional? } \\
\text { Process? } \\
\text { Individual? }\end{array}$ & $\begin{array}{l}\text { - Establish a clear public process } \\
\text { - Define where JPR fits into } \\
\text { policy process } \\
\text { - Repeat what I did }\end{array}$ & $\begin{array}{l}\text {-Inform other ministers } \\
\text { about forest issues } \\
\text { - More discussion with } \\
\text { Fl during study } \\
\text { - M ore proactive with FI }\end{array}$ & $\begin{array}{l}\text {-Add exec. personnel } \\
\text { - Change name of JPR, } \\
\text { distracting } \\
\text { - State double amt grown, not } \\
\text { double amount cut, avoid } \\
\text { negativity }\end{array}$ \\
\hline
\end{tabular}

CLFA - Crown Lands and Forest Act SW - Softwood supply JPR - "Jaakko Pöyry" Report
$\mathrm{FI}$ - Forest industry

FM - Forest management plan

APEC - Atlantic Province Economic Council 
There was clear agreement on the problem identification phase regarding softwood fibre, but not much else. The three stakeholders agreed the forest industry wanted a secure fibre supply and such an objective was lacking in all of the government's vision documents. The ENGO official also added that the CLFA (Government of New Brunswick 1980) was outdated. The EN GO has been voicing the need for more public debate regarding the role of softwood and the need for a new forest policy since the early 1990s. Only as a result of a leaked copy of the 14 September 2001 letter and through the use of the Right to Information Act (Government of New Brunswick 1978), did the ENGO confirm that a new policy initiative by the forest industry was underway. Hence, the agenda setting for the next policy round was again being set through bilateral discussions between the forest industry and government, as confirmed by the shared funding for the "Jaakko Pöyry" report.

In early 2002, at the initial stage of creating the terms of reference, the "Jaakko Pöyry" report was perceived as formulating forest policy. Both the forest industry and the government played an active role in shaping all aspects of this report. They jointly agreed on the terms of references, the hiring of the firm, the formation of a joint steering committee, and the review of the recommendations concerning the softwood supply; and they purposely avoided the larger question of reviewing the CLFA. In addition, the government and forest industry shared the cost of a second report (APEC 2003) on the socio-economic aspects of the "Jaakko Pöyry" report. M eanwhile, the EN GO strategically declined to participate in the consultation process, thereby denying the other two stakeholders the opportunity to claim that they had consulted with the "public." The ENGO also did not want to be caught between the government and the public by taking a position that did not fully represent all the views of New Brunswickers.

In terms of policy implementation, three different views emerged. The ENGO clearly voiced its concern both publicly and in theinterview that the CLFA needs to be substantially updated, especially regarding public input. In sharp contrast, consistently from 2002 to 2004, the forest industry has sought the inclusion of a timber objective in the government's overarching vision statement. They do not support any changes to the CLFA. In M arch 2003, the government official reported that a consultation process was being formulated in response to the public's negative reaction to the "Jaakko Pöyry" report in 2002. A legislative assembly committee was the preferred option. This government decision was reasonable given that both sides of the legislative assembly represented forest-community ridings. Within months this decision proved to be invaluable, when the conservative government received only a small majority in the Legislative Assembly.

Concerns loom large within the government department about policy implementation. Although it seemed reasonable to expect that the recommendations of the "Jaakko Pöyry" report would be implemented, the government decided to initiate a public consultation in late 2003; this may lead to a potential time-management problem. Changes resulting from the legislative assembly committee's report (released in September 2004) may overlap with the upcoming forest-planning cycle. Any immediate changes requested by the committee may not be achievable until the next cycle - another 5 years away. From our preliminary analysis of the committee's report (LSCWS 2004), they dealt with the cycle by spelling out a series of short, medium, and longer-term recommendations. Before the release of the committee's report, the ENGO said it was too early to conclude what change(s) might be forthcoming from implementation. Indeed, in the committee's report, nine of the 25 recommendations deal with public involvement in policymaking.

Even since the release of the committee's report in the fall of 2004, there remain differences between the stakeholders in evaluating the current situation. The ENGO continues to press for changes to the CLFA, and indeed a new forest policy. Although it is too early to know whether the recommendations from the LSCWS's report will be accepted, these recommendations do amount to significant change. Forest industry is equally adamant that no change is needed to the CLFA. Ironically, industry was initiating an agenda-setting move just as the LSCWS was being established (NBFPA 2003). The government official sees the need to prepare a review of the CFLA, which might take 3 years, along with a review of the LSCWS report. In short, after spending time, resources, and hundreds of thousands of dollars for 13 public hearings, and numerous meetings and communications between the forest industry and government, New Brunswickers can conclude that we are somewhat closer to setting a timber objective and to having more public involvement in forest policy making.

What tools did the stakeholders use during the "Jaakko Pöyry" policy-making process? Generally, there were no surprises in the tools, but they did yield one unexpected result: the ENGO used the Access to Information Act to find out what government was doing and this clearly signalled that theEN GO was not in theinner circle of influenceduring the agenda-setting phase. The ENGO effectively used radio advertisements as a "call to arms," notifying the public about the "Jaakko Pöyry" report. Their email campaign led to the formation of a Crown lands network. This concept was unexpectedly embedded in one of the LSCWS's recommendations. Both government and the forest industry used traditional communication tools - reports, and lots of them. An estimated seven reports were prepared, including the "Jaakko Pöyry" report; many are available on the New Brunswick Government's website. A very unique report is the NBDNR staff response (NBDNR 2003b) to the "Jaakko Pöyry" report. It contains a range of opinions and is worthy of a separate, more detailed examination. It served as a vehicle for department staff, including the professional foresters and scientists, to have an anonymous voice in this debate. Our own experiences in policy work show that field staff are generally not consulted as part of a policy-making process.

Improvement is always possible; it begins by becoming aware and then naming the change at the institutional, process, and individual levels (Rummler and Brache 1991). After reviewing the policy-making process and the tools employed, the three stakeholder representatives were asked what improvements they would make. All agreed that more effective institutional communications were needed. The ENGO wanted the government to establish (by law if necessary) a clear public process for forest policy. The govern- 
ment official saw the need for the minister to inform other ministers about forest issues. The forest industry representative felt that additional executive personnel would have improved the forest industry's capacity for policy making. In terms of process, improvements ranged from defining where the "Jaakko Pöyry" report fits into policy making, to wanting to have more discussions with the forest industry, to changing the name to something other than the "Jaakko Pöyry" report - the name is distracting and uninformative. At the individual level, the official from the ENGO felt that its actions showed integrity and had the intention of broader inclusion of New Brunswickers. The government official would take a more proactive approach with the forest industry and other departments. M eanwhile, the forest industry official thought he should have been more careful with words. He had stated publicly that the "Jaakko Pöyry" report recommended doubling the amount of forest to be cut, when, in fact, the report recommended doubling the amount grown - a much more positive statement.

\section{Conclusions}

Essential to policy making is a process and a body of facts. As Brooks and Miljan (2003) note, sometimes the policy path is barely visible, obscured by the struggle of conflicting interests and ideas, and by the inconsistencies and even contradictions of information and positions. They go on to conclude that appealing to the "facts" is unlikely to settle theoretical disputes when the data, let alone interpretation by the stakeholders, are contested. Both the process and the facts defining the issue were central to the actions in our examination of the policy process related to the "Jaakko Pöyry" report.

There are three significant conclusions from our research. First, the "Jaakko Pöyry" report drove a process and largely dictated the interactions between the three stakeholders examined.

The second conclusion is the major policy players were the government and the forest industry. Only after the release of the LSCWS's report (2004) was there some indication of an emerging forest-policy process. For a policy process to have existed, at a minimum this would require agreement on a policy intention within government and some level of agreement with the forest industry. From our interviews with the senior policy officials in government and the forest industry, there was no such agreement. Much to the chagrin of the ENGO, the government did not define a policy process over the 3 years under examination. Nor was the public process seen as an opportunity to become better at engaging and assessing public values and reactions to forest issues. Admittedly, enlarging the circle of those involved can be intimidating, but it can also mean there is more expertise available to define the problem and find a solution. Further research into and practice in democratizing forest policy making may well be an innovative frontier for New Brunswick to cross.

The third conclusion is that facts about forest policy making remain confusing and possibly contradictory. Two important cases illustrate this conclusion: first, the EN GO's requests about whether the "Jaakko Pöyry" consultation (during the report preparation) would indeed lead into a larger discussion on Crown land forests, or on intensive for- est management practices, went unanswered. As a result, they were left in uncertainty, and distanced themselves from the process. Second, the forest industry insisted that the CLFA must remain unchanged, but their 2003 submission to the government requested a major forest policy overhaul, including changes to the CLFA. These two positions on the CLFA are contradictory. Possibly, they feel that no changes to the CLFA should occur until agreement is reached on a new, comprehensive, forest policy.

These examples illustrate that, despite years of discussions among these three stakeholders (a subset of all the forest stakeholders), both verbal and written communications remain at the heart of both agreement and disagreement. In the next round of policy making, all three stakeholders have stated that more effective communications must be a priority. The next round has arrived. We ask: What efforts will be made to foster debate, so that more people can be made aware of and become familiar with the science-based decisions that will form forest policy and management plans in New Brunswick?

\section{Acknowledgement}

The authors wish to thank Caroline Simpson of the Atlantic Forestry Centrefor her review of and valuable comments on an earlier version of our manuscript.

\section{References $^{4}$}

Atlantic Provinces Economic Council (APEC). 2003. The New Brunswick forest industry: the potential economic impact of proposals to increase the wood supply. APEC, Halifax, NS.

Brooks, S. and L. Miljan. 2003. Public policy in Canada: an introduction. Oxford University Press, Toronto, $\mathrm{ON}$.

Cashore, B. 2001. Environmental governance: dynamics of policy change. Yale University, School of Forestry. Available on the Internet at www.yale.edu/forestry/cashore/pdfs/lenses.pdf (Accessed September 2004).

Clawson, M. 1975. Forests for whom and for what? Resources for the future, Washington, DC. The John H opkins University Press, Baltimore, M D.

Erdle, T. and Sullivan, M. 1998. Forest management design for contemporary forestry. The Forestry Chronicle 74: 378-384.

Government of New Brunswick. 1978. Right to Information Act. Assented to June 28, 1978. Available on the Internet at www.gnb.ca/0062/acts/acts/r-10-3.htm

Government of New Brunswick. 1980. Crown Lands and Forests Act. Assented to July 16, 1980. Available on the Internet at www.gnb.ca/0062/acts/acts/c-38-1.htm.

Howlett, M. and J. Rayner. The business and government nexus: principle elements and dynamics of the Canadian forest policy regime. In M. Howlett (ed.). Canadian forest policy: adapting to change. pp. 23-62. University of Toronto Press, Toronto, ON .

Jaakko Pöyry Consulting. 2002. New Brunswick Crown forests: assessment of stewardship and management. New Brunswick Department of Natural Resources and the New Brunswick Wood Products Association. Fredericton, NB. Available on the Internet at www.gnb.ca/0078/reports/jpmc.asp.

\footnotetext{
${ }^{4}$ The senior officials from thethree stakeholders are not referenced in part for reasons of anonymity and in part to allow them to share their views "off the record." Although not a typical research approach, it was useful in gaining both insights and perspective. In subsequent research, more time will be given to permit those interviewed the opportunity to review the notes for accuracy.
} 
Legislative Select Committee on Wood Supply (LSCWC). 2004. Final report on wood supply in New Brunswick. Legislative Assembly of New Brunswick, Fredericton, NB.

New Brunswick Department of Natural Resources (NBDNR). 2000. A vision for N ew Brunswick forests: goals and objectives for Crown land management. New Brunswick Department of Natural Resources and Energy, Fredericton, NB.

New Brunswick Department of Natural Resources (NBDNR). 2003a. Protected natural areas: our heritage. New Brunswick Department of Natural Resources and Energy, Fredericton, NB. Available on the Internet at www.gnb.ca/0399/our_heritage.pdf.

New Brunswick Department of Natural Resources (NBDNR). 2003b. Staff review of the Jaakko Pöyry Report. New Brunswick Crown forests: assessment of stewardship and management. N ew Brunswick Department of Natural Resources and Energy, Fredericton, NB. Available on the Internet at www.gnb.cal 0078/reports/Jaakko_Poyry_FINAL-e.pdf\#pagemode=bookmarks
New Brunswick Forest Products Association (NBFPA), 2001. Letter to Hon. Jeannot Volpé, M inister. September 14. NBFPA, Fredericton, NB.

New Brunswick Forest Products Association (NBFPA). 2003. Implementing a new forest resource policy for New Brunswick. NBFPA, Fredericton, NB.

Rummler, G. and A. Brache. 1991. Improving performance: how to manage the white space on the organization chart. Jossey Bass, San Francisco, CA.

Stefanick, L. 2001. Environmentalism and environmental actors in the Canadian forest sector. In M. Howlett (ed.). Canadian forest policy: adapting to change. pp. 157-171. University of Toronto Press, Toronto, ON.

Wilson, J. 2001. Talking the talk and walking the walk: reflections on ecosystem management ideas. In M. Howlett (ed.). Canadian forest policy: adapting to change. pp. 94-126. University of Toronto Press, Toronto, ON. 